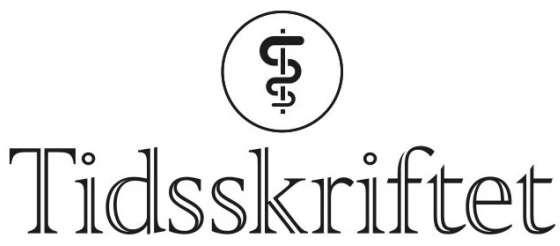

DEN NORSKE LEGEFORENING

\title{
Vil en ettertenksom student bli en god lege?
}

ANMELDELSER

TORE GUDE

Modum Bad

og

Avdeling for atferdsfag

Universitetet i Oslo

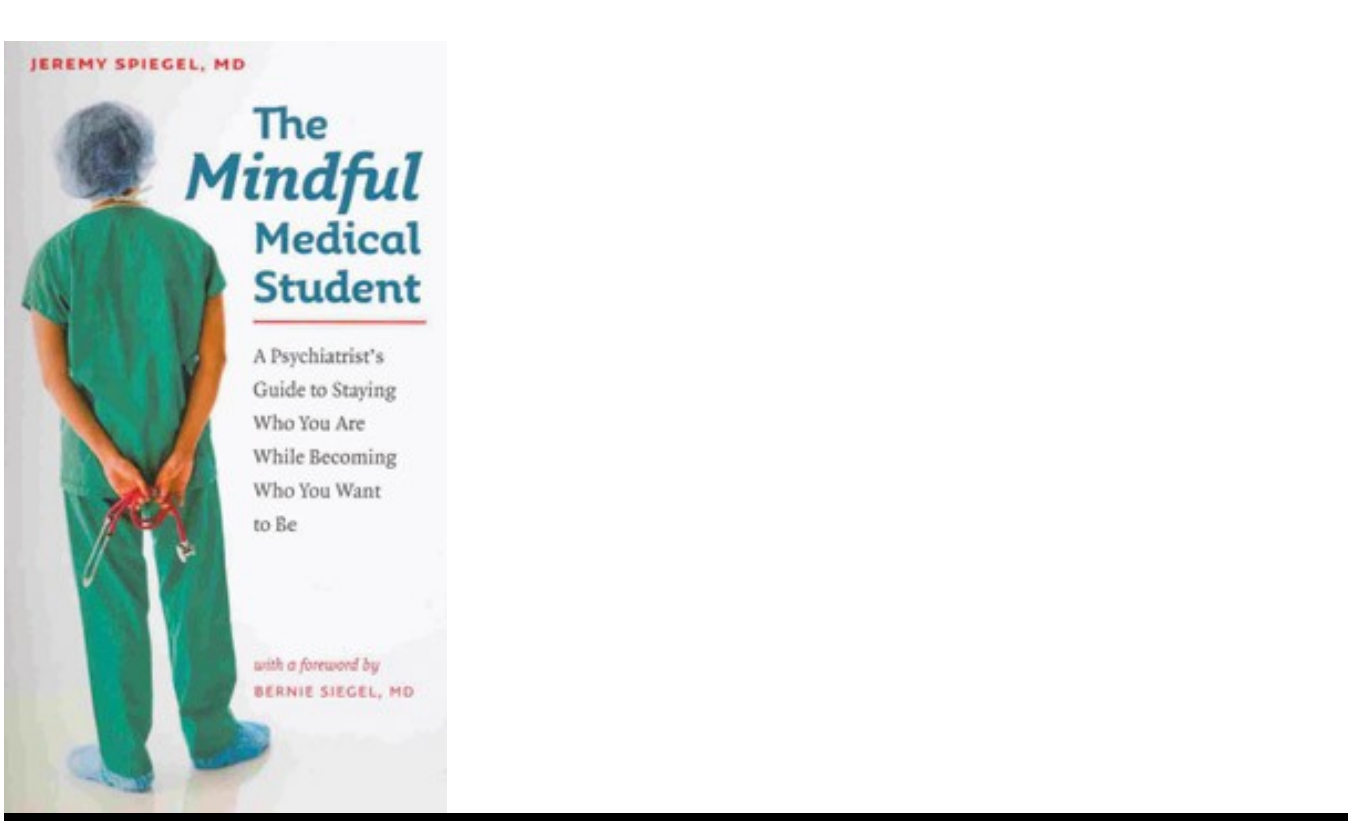

Spiegel, J.

The mindful medical student

A psychiatrist's guide to staying who you are while becoming who you want to be.

144 S. Hanover, NH: Dartmouth College Press, 2009. Pris USD 20

ISBN 978-1-58465-763-7 
Det er i alles interesse at det utdannes gode leger. Den store utfordringen er hvordan det best kan skje. Når en psykiater fra USA mener å ha funnet løsningen ved å lede medisinstudenter inn i et tilsynelatende psykologisk paradoks, vekkes nysgjerrigheten. Går det an å forbli den man er, samtidig som man skal bli den man ønsker å bli? Det skulle bare være mulig dersom man er såre fornøyd med den man er, uten å erkjenne behov for særlige endringer. Det var derfor med visse forventninger undertegnede begynte å lese. Ble så forventningene innfridd? Svaret er nei.

Forfatteren slår i forordet fast følgende: «Medical school does not create doctors, medical students must transform themselves into doctors by using their own inner resources in addition to the information and expertise they absorb from their training». Videre målbærer han hensikten med boken som er å tilby verdifull innsikt til dagens medisinstudenter slik at de kan tilegne seg emosjonell, like mye som teoretisk og praktisk læring. Det er i seg selv et godt formål. Det avgjørende er imidlertid om oppskriften virker. Forfatteren legger hovedvekten på psykologisk bevisstgjøring hos den enkelte studenten for å styrke egen identitet gjennom selvhjelp og selvinstruksjon. Hvordan studiet kan bidra til at emosjonell læring kan gå hånd i hånd med den medisinske kunnskapstilegnelsen, blir ikke vektlagt. Det er her forventningene ikke innfris.

Boken er inndelt i tre hovedbolker: Oppdag hvem du er, gjenoppdag deg selv og stak ut en vei mot dypere forståelse. I underkapitler tar man opp viktige temaer, som å motarbeide utagering (impulsiv og ureflektert handling overfor et annet individ), å forebygge utbrenthet og å unngå fagidioti. Selv om forfatteren prøver å anvende et folkelig språk, blir det mye teori, til dels krevende psykologiske begreper, f.eks. arketyper og det sanne selv, henholdsvis det falske selv. Istedenfor å bli så opptatt av å utdype disse begrepene, kunne forfatteren gått mer inn på hvordan studiet kan designes for å gi studentene styrket egenopplevelse av måter å takle krevende kliniske situasjoner på. Vi som underviser medisinstudenter, opplever at de etterlyser mer konkret, konstruktiv og kritisk tilbakemelding på sin måte å mestre slike situasjoner på. Når undervisningen skjer i smågrupper med lærere som kan legge til rette for en trygg atmosfære, kan det gi grunnlag for emosjonell læring når studentene tør både fortelle om og reflektere over sine vanskelige opplevelser i krevende situasjoner. Det er sannsynligvis mer virkningsfullt enn å lese denne boken som neppe vil bli noen bestselger blant medisinstudenter, selv om forfatterens intensjon er aldri så god. En god norsk oversettelse kunne kanskje endret denne vurderingen ved at stoffet derved ville blitt lettere tilgjengelig for norske medisinstudenter.

Svaret på spørsmålet i overskriften til denne bokanmeldelsen blir at ettertenksomhet er bra, men ikke tilstrekkelig for å bli en god lege. Læring, som er nødvendig over lengre tid enn varigheten av et medisinstudium, må skje gjennom en integrering av medisinske ferdigheter og utvikling av den enkeltes personlige trygghet, som grunnlag for å utvikle en god og funksjonell identitet som lege.

Publisert: 26. august 2010. Tidsskr Nor Legeforen. DOI: 10.4045/tidsskr.10.0259

(C) Tidsskrift for Den norske legeforening 2023. Lastet ned fra tidsskriftet.no 26. april 2023. 